DOI: https://doi.org/10.24144/2409-6857.2021.1(57).114-120

УДК 336.71:336.77

\title{
Заславська O.I.
}

\section{АНАЛІЗ ТА ОЦІНКА СУЧАСНОГО СТАНУ РОЗДРІБНОГО БАНКІВСЬКОГО БІЗНЕСУ В УКРАЇНІ У СФЕРІ КРЕДИТУВАННЯ}

\begin{abstract}
У статті розглянуто питання розвитку роздрібного банківського кредитування в Украӥні. Проведено аналіз динаміки активів і кредитного портфеля банків Украӥни. Досліджено особливості формування роздрібного кредитного портфеля украйнських банків, здійснено аналіз його структури та якості у 2015 2019 роках. Представлено результати аналізу процентної політики українських банків у сфері роздрібного кредитування. Окреслено напрями вдосконалення системи банківського менеджменту на кредитному ринку роздрібних послуг у контексті впровадження інновачійних технологій у сферу банківського бізнесу в Україні.
\end{abstract}

Ключові слова: банківські послуги, роздрібний банківський бізнес, кредитні роздрібні банківські послуги, роздрібний кредитний портфель, банківські інформаційні технології, банківські інновації.

Постановка проблеми. Ефективне функціонування сучасної банківської системи забезпечують стратегії розвитку, орієнтовані на обслуговування населення та суб'єктів малого підприємництва. Орієнтацію діяльності українських банків на роздрібний бізнес пов'язано із кризовими явищами в економіці, посиленням конкуренції за клієнтів та гідне місце на фінансовому ринку, а також зі стрімкою діджиталізацією банківського бізнесу. Впровадження інформаційних технологій, створення нових банківських продуктів, активізація інноваційної маркетингової діяльності банків здатні суттєво підвищити рентабельність i прибутковість роздрібного бізнесу як окремих банків, так і банківського сектору економіки загалом. Ефективне функціонування роздрібного банківського бізнесу в Україні значною мірою визначається рівнем розвитку роздрібного кредитування, який $€$ ключовим сегментом діяльності банків і одним із основних джерел їхніх доходів.

Аналіз останніх досліджень і публікацій. Теоретичні та практичні аспекти організації роздрібного банківського бізнесу висвітлено у працях багатьох відомих зарубіжних та українських вчених-економістів. Серед відомих зарубіжних науковців, які зробили вагомий внесок у дослідження банківського ритейлу, слід відзначити таких, як Х.-У. Деринг, Гр. Р. Клаус, М. Ланглет, Г. Маклеод, Дж. Ст. Мілль, Х. Мінскі, М. Портер, П. Роуз, Дж. Б. Самерс, К. Тімоті, Ж. Тіроль, Д. Хамфрі та інші.

(C) Заславська O.I., к.е.н., доц. доцент кафедри фінансів і банківської справи, ДВНЗ «Ужгородський національний університет», м. Ужгород, тел.: +380501011695, e-mail: olga.zaslavska@uzhnu.edu.ua

114
Особливості розвитку ринку банківських роздрібних послуг в Україні досліджено у наукових працях таких вітчизняних вчених, як М. Алексеєнко, О. Васюренко, О. Вовчак, О. Дзюблюк, С. Єгоричева, А. Єпіфанов, І. Івасів, О. Комісарчик, О. Купрієнко, М. Крупка, І. Лютий, В. Міщенко, А. Мороз, Л. Примостка, М. Савлук та інші. Віддаючи належне їх значному внеску у вивчення зазначеної проблематики, слід зазначити, що існує потреба в аналізі сучасного стану роздрібного кредитування у вітчизняному банківському секторі як найбільш прибуткового сегменту банківського бізнесу.

Формулювання цілей статті. Метою статті $\epsilon$ дослідження особливостей розвитку вітчизняного ринку кредитних банківських послуг, аналіз роздрібного кредитного портфеля українських банків, a також обгрунтування напрямів підвищення ефективності системи кредитування фізичних осіб та суб'єктів малого бізнесу в Україні.

При написанні статті використано загальноприйняті наукові методи дослідження. Метод порівняльного аналізу використано для оцінки кредитної діяльності банків на ринку роздрібних банківських послуг; метод групування та узагальнення економічних показників - для дослідження динаміки кредитного портфеля банків; абстрактно-логічний метод - для визначення шляхів підвищення ефективності ринку кредитних банківських послуг; графічний i табличний методи - для представлення результатів дослідження.

Опис основного матеріалу дослідження. Дослідження кредитної діяльності банківського сектору України на роздрібному ринку доцільно розглядати у контексті оцінки структури та якості його кредитного портфеля загалом. Результати проведеного аналізу показали, що протягом 2015- 
2020 років кредитна активність українських банків знизилася на 16,2 \%. Залишалася низькою і якість кредитного портфеля, про що свідчить частка непрацюючих кредитів (NPLs), яка на кінець 2020 року склала 48,4 \%. Найбільше значення частки непрацюючих кредитів на рівні $54,5 \%$ було зафіксовано у 2017 році. Для порівняння, у докризовому 2013 році непрацюючі кредити у кредитному портфелі банків складали 8,1\% [3].

Структуру i якість кредитного портфеля банківського сектору України представлено у табл. 1

Динаміка активів і кредитного портфеля банків України

Таблиця 1 у 2015-2019 рр. (на кінець року, млрд. грн.)*

\begin{tabular}{|l|c|c|c|c|c|c|c|}
\hline \multicolumn{1}{|c|}{ Показник } & $\mathbf{2 0 1 5}$ & $\mathbf{2 0 1 6}$ & $\mathbf{2 0 1 7}$ & $\mathbf{2 0 1 8}$ & $\mathbf{2 0 1 9}$ & $\begin{array}{c}\text { Темп } \\
\text { приросту } \\
\text { до } \\
\text { базового } \\
\text { року, \% }\end{array}$ & $\begin{array}{c}\mathbf{2 0 2 0} \\
\text { (станом } \\
\text { на 01.09) }\end{array}$ \\
\hline $\begin{array}{l}\text { Активи банків, } \\
\text { у млрд. грн. }\end{array}$ & 1254,4 & 1256,3 & 1333,8 & 1359,7 & 1493,3 & 19,1 & 1651,6 \\
\hline $\begin{array}{l}\text { Кредитний } \\
\text { портфель банків, } \\
\text { улрд. грн. }\end{array}$ & 1009,7 & 1005,9 & 1036,7 & 1118,9 & 1033,4 & 2,3 & 1062,8 \\
\hline $\begin{array}{l}\text { Частка кредитів у } \\
\text { активах, \% }\end{array}$ & 80,5 & 80,1 & 77,7 & 82,3 & 69,2 & - & 64,3 \\
\hline $\begin{array}{l}\text { Непрацюючі } \\
\text { кредити (NРLs), } \\
\text { млрд. грн. }\end{array}$ & 370,24 & 407,67 & 594,99 & 630,76 & 530,78 & 43,4 & 575,420 \\
\hline $\begin{array}{l}\text { Частка NРLs } \\
\text { у кредитному } \\
\text { портфелі, \% }\end{array}$ & 36,7 & 32,5 & 54,54 & 52,85 & 48,36 & - & 48,92 \\
\hline $\begin{array}{l}\text { Кредити } \\
\text { суб'сктам } \\
\text { господарювання, у } \\
\text { млрд. грн. }\end{array}$ & 830,6 & 847,1 & 864,4 & 919,1 & 821,9 & $-1,0$ & 839,9 \\
\hline $\begin{array}{l}\text { Частка у } \\
\text { кредитному } \\
\text { портфелі, \% }\end{array}$ & 82,3 & 84,2 & 83,4 & 82,1 & 79,5 & - & 79,0 \\
\hline $\begin{array}{l}\text { Кредити фізичним } \\
\text { особам, у млрд. } \\
\text { грн. }\end{array}$ & 175,7 & 157,4 & 170,8 & 196,9 & 206,7 & 17,6 & 217,4 \\
\hline $\begin{array}{l}\text { Частка у } \\
\text { кредитному } \\
\text { портфелі, \% }\end{array}$ & 17,4 & 15,6 & 16,5 & 17,6 & 20,0 & - & 20,4 \\
\hline
\end{tabular}

*Джерело: складено на основі [3]

Наведені дані демонструють, що і активи, i кредитний портфель вітчизняних банків протягом аналізованого періоду показали хоча й незначну, але позитивну динаміку зростання. Обсяг активів банківського сектору зріс на на $19,1 \%$, а клієнтський кредитний портфель збільшився на $2,3 \%$. Станом на 01.09.2020 р. його обсяг складав 1062,8 млрд. грн., що становить 64,3 \% обсягу активів, у той час як у 2015 році частка кредитів в активах складала 80,5\%. Частка непрацюючих кредитів протягом періоду збільшилася на 43,4\%, проте, починаючи із 2017 року, вона щорічно зменшувалася, що свідчить про ефективність організації роботи банків із проблемною заборгованістю. Так, на кінець 2020 року непрацюючі кредити вже не становили загрози стійкості банківської системи завдяки створеним у банках резервам, рівень покриття якими становив 95,2 \% [5].

Результати аналізу кредитного портфеля показали, що у 2015-2020 pp. українські банки було зорієнтовано на кредитування корпоративних позичальників - частка наданих їм кредитів у середньому становила 79,6 \% усього 
обсягу. Частка роздрібних кредитів у загальному кредитному портфелі банків становила $17,4 \%$ у 2015 році і 20,4 \% у 2020 році. Обсяг роздрібного кредитного портфеля протягом періоду зріс на $17,6 \%$ і склав 217,4 млрд. грн. Головним чином це сталося за рахунок зростання споживчих кредитів, частка яких у середньому за період становила 71,5\% усіх роздрібних кредитів [3].

Аналіз структури роздрібного кредитного портфеля українських банків засвідчив домінування у ньому споживчих кредитів. На початку періоду їх обсяг складав 137,3 млрд. грн., а станом на 01.09.2020 р. зріс до 182,2 млрд. грн., тобто на 75,4 \%. Частка споживчих кредитів у їх загальному обсязі зросла із 59,7 \% до 83,8 \%. Причиною зростання споживчих кредитів у 2017 2019 роках стала висока дохідність сегменту, що спонукало банки видавати більше кредитів. I3 боку позичальників активний попит на кредити зумовило зростання доходів населення та відповідне поліпшення споживчої впевненості.
Обсяг кредитів, наданих населенню на придбання, будівництво та реконструкцію нерухомості, зменшувався щорічно, починаючи із 66,2 млрд. грн. у 2015 році до 35,5 млрд. грн. у 2020 році, тобто на 46,4\%. Варто зазначити, що у структурі роздрібного кредитного портфеля банків іпотечні кредити протягом усього періоду не перевищували 20,0 \%. Така ситуація вказує на те, що наразі українські банки більшою мірою готові надавати дороговартісні короткострокові та карткові кредити [3].

У табл. 2 наведено показники обсягів кредитів, наданих фізичним особам за цільовим спрямуванням коштів, із зазначенням відповідних строків погашення. Якість роздрібного кредитного портфеля банків значною мірою визначається наявністю стійкої тенденції до зростання довгострокового кредитування, яке би свідчило про можливості банків формувати відповідну ресурсну базу, а також можливості фізичних осіб погашати такі позики.

Роздрібний кредитний портфель банківського сектору України

Таблиця 2 за цільовим спрямуванням коштів і строками погашення у 2015-2019 рр. (на кінець року, у

\begin{tabular}{|l|c|c|c|c|c|c|c|}
\multicolumn{1}{|c|}{ Показник } & $\mathbf{2 0 1 5}$ & $\mathbf{2 0 1 6}$ & $\mathbf{2 0 1 7}$ & $\mathbf{2 0 1 8}$ & $\mathbf{2 0 1 9}$ & $\begin{array}{c}\text { Мриро } \\
\text { просту } \\
\text { до } \\
\text { базового } \\
\text { року, \% }\end{array}$ & $\begin{array}{c}\mathbf{2 0 2 0} \\
\text { (станом } \\
\text { на 01.09) }\end{array}$ \\
\hline $\begin{array}{l}\text { Кредити фізичним } \\
\text { особам, усього }\end{array}$ & 175,7 & 157,4 & 170,8 & 196,9 & 206,7 & 17,6 & 217,4 \\
\hline $\begin{array}{l}\text { Споживчі кредити, у } \\
\text { т. ч. за строками: }\end{array}$ & 104,9 & 101,5 & 122,1 & 151,6 & 173,7 & 65,6 & 182,2 \\
\hline до 1 року & 33,3 & 34,3 & 42,6 & 69,7 & 89,2 & 167,7 & 99,7 \\
\hline від 1 до 5 років & 29,5 & 27,8 & 45,2 & 49,2 & 59,8 & 102,7 & 59,3 \\
\hline понад 5 років & 42,0 & 39,4 & 34,2 & 32,7 & 24,7 & $-41,2$ & 26,1 \\
\hline $\begin{array}{l}\text { Кредити на } \\
\text { нерухомість, у т. ч. } \\
\text { за строками: }\end{array}$ & 66,2 & 58,5 & 48,3 & 44.4 & 32,6 & $-50,7$ & 35,5 \\
\hline до 1 року & 6,3 & 3,6 & 1,3 & 1,1 & 0,6 & $-90,5$ & 0,7 \\
\hline від 1 до 5 років & 3,3 & 2,5 & 1,9 & 1,7 & 1,6 & $-51,5$ & 1,7 \\
\hline від 5 до 10 років & 7,7 & 7,5 & 8,7 & 8,8 & 6,7 & $-12,9$ & 7,4 \\
\hline понад 10 років & 48,8 & 44,9 & 36,4 & 32,8 & 23,7 & $-51,4$ & 25,6 \\
\hline $\begin{array}{l}\text { Інші кредити, у т.ч. } \\
\text { за строками }\end{array}$ & 3,8 & 3,2 & 3,8 & 5,0 & 6,2 & 63,2 & 6,1 \\
\hline до 1 року & 1,0 & 1,0 & 2,0 & 2,4 & 2,8 & 180 & 1,8 \\
\hline від 1 до 5 років & 1,7 & 1,4 & 1,4 & 2,3 & 3,2 & 88,2 & 3,9 \\
\hline понад 5 років & 1,0 & 0,8 & 0,4 & 0,3 & 0,2 & $-80,0$ & 0,3 \\
\hline
\end{tabular}

*Джерело: складено на основі [3]

Дані, наведені у табл. 2, свідчать, що на кінець 2019 року обсяги споживчих кредитів із строками погашення до 1 року і від 1 року до 5 років зросли на $167,2 \%$ і на $102,7 \%$, відповідно. Натомість 116 споживчі кредити, надані на термін понад 5 років, зменшилися на 41,2 \%. Щодо іпотечних кредитів, то за строками погашення спостерігалася тенденція до їх зменшення: кредити, надані на 
термін до 1 року, зменшилися на 90,5 \%, а на понад 10 років - на $51,4 \%$.

Структура роздрібного кредитного портфеля у розрізі строковості на кінець аналізованого періоду виглядала так. Споживчі кредити, надані на термін понад 5 років, становили $14,2 \%$; від 1 го до 5-ти років і до 1-го року - 34,4 \% та 51,4, \%, відповідно. Іпотечні кредити, надані на термін понад 10 років, складали 72,7 \%; від 5-ти до 10-ти років - 20,5 \%; від 1-го до 5-ти років - 4, $9 \%$; до 1-го року - $1,8 \%$ [3].

Варто зазначити, що до цього часу у кредитному портфелі вітчизняних банків високою залишається частка кредитів в іноземній валюті (34,67 \% станом на 01.01.2020р.), що свідчить про високий рівень доларизації балансів банків. Утім, високу частку кредитів в іноземній валюті спричинено не наданням нових кредитів, а девальвацією гривні, внаслідок чого обсяги кредитів в іноземній валюті у перерахунку на національну валюту зросли. Основна частка валютних кредитів - це кредити, надані населенню ще у 2008-2009 рр. на придбання та будівництво нерухомості. У зв'язку зі зменшенням реальних доходів чимало

позичальників не мають можливості і надалі погашати свої кредити, що спричиняе наявність значної проблемної заборгованості на фоні скорочення кредитного портфеля.

Важливим напрямом аналізу роздрібного кредитного портфеля банківського сектору $€$ оцінка його процентної політики, адже відсоткові ставки за кредитами $\epsilon$ не лише джерелом доходів банків, але й джерелом ризику. Банки наражаються на ризик фінансових втрат внаслідок змін відсоткових ставок за активами та зобов'язаннями через надання кредитів iз фіксованою відсотковою ставкою у сумах та на строк, що відрізняються від сум та строків зобов'язань із фіксованою відсотковою ставкою.

У табл. 3 представлено результати аналізу процентної політики українських банків у сфері роздрібного кредитування у 2015-2020 pp. Результати дослідження динаміки відсоткових ставок за кредитами фізичних осіб засвідчили, що протягом аналізованого періоду середньозважена відсоткова ставка за кредитами у національній валюті зросла на 4,8 в.п. до 33,1 \%, а в іноземній валюті зменшилася на 5,2 в.п. до 9,0\%.

Таблиця 3

Відсоткові ставки украӥнських банків за кредитами фізичних осіб у розрізі валют і строків погашення у 2015-2019 рр. (на кінець року, \%)*

\begin{tabular}{|l|c|c|c|c|c|c|c|}
\hline \multicolumn{1}{|c|}{ Показник } & $\mathbf{2 0 1 5}$ & $\mathbf{2 0 1 6}$ & $\mathbf{2 0 1 7}$ & $\mathbf{2 0 1 8}$ & $\mathbf{2 0 1 9}$ & $\begin{array}{c}\text { Абсолютний } \\
\text { приріст } \\
\mathbf{2 0 1 9 / 2 0 1 5}\end{array}$ & $\begin{array}{c}\text { 2020 } \\
\text { (станом } \\
\text { на 01.09) }\end{array}$ \\
\hline $\begin{array}{l}\text { Середньозважена } \\
\text { відсоткова ставка y } \\
\text { національній валюті, } \\
\text { у тому числі: }\end{array}$ & 28,3 & 30,7 & 29,2 & 30,4 & 33,1 & 4,8 & 31,3 \\
\hline до 1 року & 29,3 & 30,7 & 29,5 & 30,6 & 37,5 & 8,2 & 37,0 \\
\hline від 1 до 5 років & 30,6 & 32,8 & 29,5 & 33,6 & 29,8 & $-0,8$ & 31,7 \\
\hline понад 5 років & 13,3 & 16,6 & 21,7 & 20,2 & 21,5 & 8,2 & 18,1 \\
\hline $\begin{array}{l}\text { Середньозважена } \\
\text { відсоткова ставка в } \\
\text { іноземній валюті, } \\
\text { у тому числі: }\end{array}$ & 14,2 & 14,3 & 16,1 & 11,6 & 9,0 & $-5,2$ & 21,9 \\
\hline до 1 року & 12,5 & 2,8 & 6,7 & 10,7 & 8,9 & $-3,6$ & 5,7 \\
\hline від 1 до 5 років & 11,2 & 11,7 & 10,5 & 8,3 & 8,3 & $-2,9$ & 8,5 \\
\hline понад 5 років & 10,3 & 8,3 & 9,4 & 8,2 & 8,5 & $-1,8$ & 8,6 \\
\hline
\end{tabular}

*Джерело: складено на основі [3]

Аналіз відсоткових ставок за споживчими кредитами, наданими у національній валюті у розрізі строковості, показав, що ціна кредитів до 1 року є значно вищою за ціну кредитів, наданих на термін понад 5 років: 37,0 \% проти 18,1 \% у 2020 році. Вартість кредитів до 1-го року та понад 5 років протягом періоду зросла на 8,2 в.п., а вартість кредитів та від 1-го до 5-ти років суттєво не змінилася і становила $31,7 \%$.
Дані НБУ щодо вартості кредитів для населення свідчать про те, що протягом аналізованого періоду найдорожчими були кредити готівкою, відсоткова ставка за якими складала у середньому 79,3 \% річних. Відсоткова ставка за картковими кредитами у середньому становила 60,5 \%. Високі значення кредитних ставок пояснюються високими ризиками цих видів кредитування, адже 
такі позики надаються без забезпечення та гарантій [3].

Що стосується вартості роздрібних кредитів в іноземній валюті, то протягом періоду вони знизилися за всіма строками надання у середньому на 3,1 в.п. і на кінець аналізованого періоду становили 8,5 \%. У цьому аспекті варто зазначити, що згідно із чинним законодавством України, з 2011 року фізичним особам заборонено надавати кредит в іноземній валюті. Національний банк зобов'язав банки надавати валютні кредити юридичним особам малого бізнесу та підприємцям виключно для оплати їх зовнішньоекономічних зобов'язань.

Дослідження ринку роздрібних банківських послуг в Україні дозволило виявити основні проблеми його функціонування та визначитися із напрямами вдосконалення організації кредитних послуг у контексті впровадження у сферу роздрібного бізнесу новітніх моделей управління, технологій та продуктів, зважаючи на сучасні українські політичні та економічні реалії. У сфері роздрібного банківського бізнесу в Україні протягом останніх років найбільш вагомим ризиком $\epsilon$ ризик неповернення кредитів. У портфелі кредитів, наданих фізичним особам українськими банками, частка непрацюючих кредитів (NPLs) у 2019 році складала 36 \% його обсягу. Експерти зазначають, що практично всі кредити, що наразі визнано непрацюючими, це іпотечні кредити, надані фізичним особам до 2015 року. Нехтування стандартами ризикменеджменту з боку банків призвело до суттєвих втрат за такими кредитами під час кризи 20142016 pp. [3].

В останні роки на вітчизняному ринку роздрібних банківських послуг стрімко зростає споживче кредитування. При цьому переважна більшість банків продовжують послаблювати стандарти схвалення кредитних заявок. На думку експертів НБУ, банки недостатньо жорстко оцінюють ризики за незабезпеченими споживчими кредитами. Оцінки ймовірностей дефолтів та втрат у разі дефолтів, зважаючи на сьогоднішні реалії в економіці держави, є дещо заниженими. Попри те, що рівень проникнення споживчих кредитів на сьогодні є меншим, ніж 5 \% від ВВП, темпи їх зростання є дуже високими. У 2019 році відношення нових споживчих кредитів до приватного споживання сягнуло майже $9 \%$. Кредитування стало помітним чинником внутрішнього споживання. Щоби не допустити накопичення системних ризиків, iз 2021 року НБУ планує запровадити підвищені критерії оцінки ризику для незабезпечених споживчих кредитів [3].
Із метою вдосконалення системи управління проблемною заборгованістю Національний банк України затвердив «Положення про організацію процесу управління проблемними активами у банках України», де зокрема зазначено, що банки зобов'язані розробити та запровадити спеціальні процедури врегулювання заборгованості за непрацюючими кредитами. Вибір відповідних інструментів залежатить від потенційної платоспроможності боржника та його готовності співпрацювати 3 банком. Банки, в яких рівень проблемних активів перевищує 5 \%, зобов'язано створити постійно діючий підрозділ для роботи 3 такими активами. Важливим кроком у кредитуванні малого бізнесу стали заходи НБУ, згідно 3 якими спрощуються умови кредитування фізичних осіб-підприємців. Запроваджені зміни значно спрощують підприємцям малого бізнесу доступ до банківських кредитів [5].

Одним iз системних ризиків української економіки сьогодні $\epsilon$ висока доларизація банківської системи. У грудні 2019 року Національним банком України було прийнято рішення, спрямоване на дедоларизацію банківських балансів. Змінено вимоги до обов'язкових резервів банків. Для гривневих коштів встановлено нульову ставку резервування, а для валютних - $10 \%$, що повинно сприяти активізації банківського кредитування та дедоларизації банківських балансів [4].

Важливу роль у підвищенні якості роздрібного кредитного портфеля банків відведено Закону України «Про споживче кредитування», який вступив у дію у червні 2017 року. На думку експертів Асоціації українських банків, новий закон поверне довіру між банками та населенням. Законом передбачено відповідальність за недостовірну інформацію щодо відсоткових ставок за кредитами. Це стосується і так званих «нульових ставок», яких у банківській практиці бути не може за визначенням. Затверджено також порядок виплати за простроченими кредитами на користь боржника, a не банку. Зокрема, насамперед сплачується тіло кредиту із відсотками і тільки після цього - штрафи за порушення строків погашення тощо [6].

Зважена кредитна політика банків зі встановлення відсоткових ставок, постійний моніторинг складових кредитного портфеля та управління ризиками мають призвести до зростання обсягів роздрібного кредитування i вдосконалення системи управління якістю кредитного портфеля. Зважаючи на нинішні економічні реаліі, фахівці пропонують такі напрями підвищення ефективності кредитної діяльності українських банків: 
- перманентний аналіз відносин iз позичальниками 3 метою оцінки їх кредитоспроможності та виявлення потенційних ризиків;

- обгрунтована оптимізація кредитного портфеля банків за приорітетними ознаками категорією позичальників, строковістю кредитів та дохідністю;

- вибір дієвих методик оцінки якості та ефективності кредитного портфеля банків із використанням сучасних методів аналізу;

- перегляд депозитної політики, пошук інноваційних шляхів зміцнення та нарощення ресурсної бази банків;

- встановлення жорстких вимог до процесу кредитування як із боку банку, так і з боку позичальників;

- забезпечення ефективного кредитного ризикменеджменту у банках;

- розроблення ефективної системи заходів щодо організації роботи із непрацюючими кредитами;

- удосконалення кредитної політики банків на ринку роздрібних послуг;

- упровадження інновацій у сферу роздрібного кредитування [1;2].

Одним iз основних напрямів підвищення ефективності банківського бізнесу за сучасних умов $є$ цифровізація банківської діяльності, покликана трансформувати не лише методи розширення клієнтських баз банку та просування нових банківських продуктів, але й докорінно змінити організаційні засади банку як суб'єкта господарської діяльності.

Висновки i перспективи подальших досліджень. Дослідження ринку роздрібного банківського кредитування в Україні дозволило визначити основні тенденції та проблеми його розвитку, а також визначитися із напрямами його вдосконалення, що передбачає виконання таких умов, як: нормативно-правове забезпечення діяльності суб'єктів ринку; якісний маркетинг i менеджмент банку; високий рівень впровадження інформаційних технологій; наявність портфеля сучасних банківських послуг; ринкове ціноутворення; державне регулювання ринку роздрібних банківських послуг. Необхідною умовою успішного розвитку роздрібного банківського бізнесу в Україні $є$ впровадження інноваційних технологій. Застосування цифрових технологій вимагає від банків розробки стратегії, яка передбачає формування нової якості обслуговування клієнтів; розроблення нових та удосконалення існуючих продуктів; впровадження нових та удосконалення наявних каналів збуту; формування діджиталорієнтованого персоналу тощо.

\section{ПЕРЕЛІК ВИКОРИСТАНИХ ДЖЕРЕЛ}

1. Банківська система України: інституційні зміни та інновації: монографія / Л. О. Примостка, М. І. Диба та ін. - К.: КНЕУ, 2015. - 434 c.

2. Новікова Т. Сучасні підходи до формування маркетингової стратегії розвитку банківської системи України в умовах глобалізації та євроінтеграції / Т. Новікова, Ю. Котелевська // Вісник університету банківської справи НБУ. - 2017. - № 2 (17). - С. 152-156.

3. Офіційний сайт Національного банку України // Електронний ресурс. - Режим доступу: www.bank.gov.ua.

4. Положення про організацію системи управління ризиками в банках України та банківських группах / Постанова НБУ №64 від 11.06.2018 p. - Електронний ресурс. - Режим доступу: http://zakon.rada.gov.ua.

5. Про затвердження Положення про організацію процесу управління проблемними активами в банках України / Постанова НБУ №97 від 18.07.2019 р. - Електронний ресурс. - Режим доступу: http://zakon.rada.gov.ua.

6. Про споживче кредитування /Закон України № 1734-VIII від 15.11.2016 р. - Електронний ресурс. - Режим доступу: http://zakon.rada.gov.ua.

\section{REFERENCES}

1. Prymostka, L.O., \& Dyba, M.I. (2015). Bankivska systema Ukrayiny: instytutsiyni zminy ta innovatsiyi: monohrafiya [Banking system of Ukraine: institutional changes and innovations: monograph]. K.: KNEU [in Ukrainian].

2. Novikova, T. (2017). Suchasni pidkhody do formuvannya marketynhovoyi stratehiyi rozvytku bankivskoyi systemy Ukrayiny $\mathrm{v}$ umovakh hlobalizatsiyi ta yevrointehratsiyi [Modern approaches to the formation of marketing strategy for the development of the banking system of Ukraine in the context of globalization and European integration]. Visnyk universytetu bankivskoyi spravy NBU - Bulletin of the University of Banking of the NBU, 2 (17), 152-156 [in Ukrainian]. 3. Ofitsiynyy sayt Natsionalnoho banku Ukrayiny [Official site of the National Bank of Ukraine]. Retrieved from:: www.bank.gov.ua [in Ukrainian].

4. Polozhennya pro orhanizatsiyu systemy upravlinnya ryzykamy $\mathrm{v}$ bankakh Ukrayiny ta bankivskykh hruppakh. Postanova NBU №64 vid 11.06.2018 r. [Regulations on the organization of the risk management system in banks of Ukraine and banking groups. Resolution of the NBU № 64 from June 11, 2018]. (2018). Retrieved from: http://zakon.rada.gov.ua [in Ukrainian]. 
5. Pro zatverdzhennya Polozhennya pro orhanizatsiyu protsesu upravlinnya problemnymy aktyvamy $\mathrm{v}$ bankakh Ukrayiny. Postanova NBU № 97 vid 18.07.2019 r. [On approval of the Regulations on the organization of the process of management of problem assets in the banks of Ukraine. Resolution of the NBU № 97 from July 18, 2019]. (2019). Retrieved from: http://zakon.rada.gov.ua [in Ukrainian].

6. Pro spozhyvche kredytuvannya. Zakon Ukrayiny № 1734-VIII vid 15.11.2016 r. [On consumer lending. Law of Ukraine № 1734-VIII from November 15, 2016]. (2016). Retrieved from: http://zakon.rada.gov.ua. [in Ukrainian].

Отримано 03.03.2021 